\title{
Groundwater reserve and capacity of groundwater extraction for IImenite placer mining in Ninh Thuan province
}

\section{- Dang Thuong Huyen}

Faculty of Geology and Petroleum Engineering, University of Technology, VNU-HCM

- Hoang Thi Thanh Thuy

- Trinh Hong Phuong

Faculty of Geology, University of Natural Resources and Environment, Ho Chi Minh City

(Manuscript Received on August 18, 2014 ; Manuscript Revised Novemben 13 ${ }^{\text {th }}$,2014)

\section{ABSTRACT:}

Mining ilmenite placer develops quickly along the coastal zone in the center area, Vietnam. In Ninh Thuan province, the mines are mostly using water for the exploitation. We simulated groundwater flow with uncertain parameters in order to answer if groundwater can supply a part of water demand for the exploitation of ilmenite by using GMS software. Unfortunately, as the results of simulation, groundwater is not enough to supply for ilmenite exploitation. The authors calculated the ilmenite reserves in several communes in Ninh Thuan and water demands. Comparison of water demands and ability of groundwater supply concludes that local government should make a sustainable strategy of water use to preserve groundwater.

Keywords: ilmenite placer, groundwater modeling

\section{INTRODUCTION}

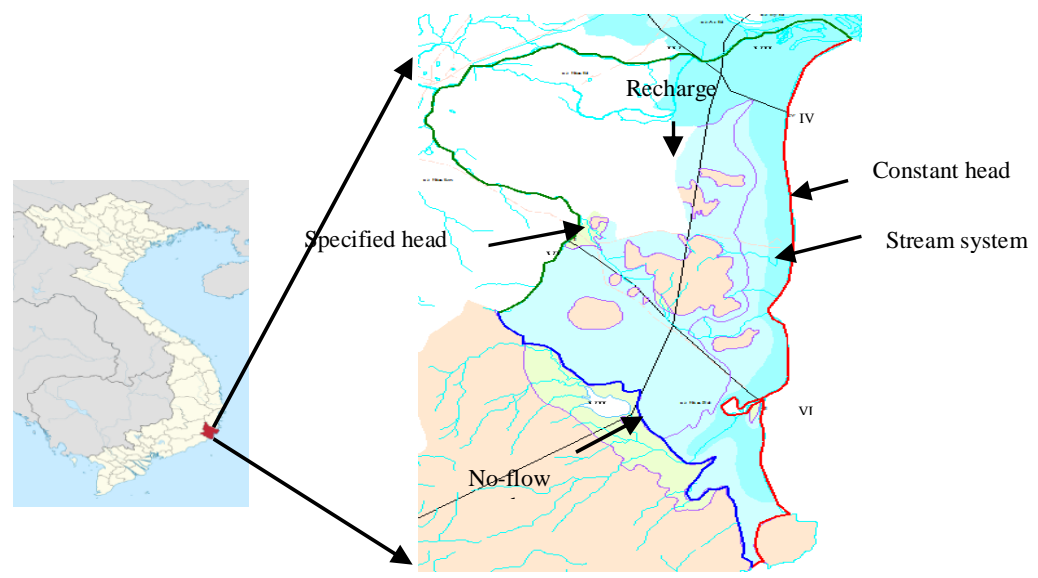

Figure 1. The study area and conceptual model

An Hai and Phuoc Hai Communes belong to Ninh Phuoc district, Phuoc Dinh belongs to Thuan Nam district are selected as the study area (Fig. 1). The total area is about 11320 ha with 41000 residents. Local people are using both groundwater and surface water for their livings and irrigation as well. These communes are in the area that the national government gave the ilmenite exploitation license to mining companies. The area is bounded by Dinh river in the north, the Lu river

\section{Trang 34}


and Tam Lang stream in the south, a coastal line in the east, and a mountain in the west - south.

\section{GROUNDWATER MODELING INPUTS}

Ilmenite reserves and water demand

Ilmenite placer reserves are about 17.2 million tons distributing on 3988 ha. To mine this ilmenite reserves, it needs about 2.5 billion $\mathrm{m}^{3}$ of water. The period of ilmenite exploitation is 12 years. It means water should supply averagely about 209 million $\mathrm{m}^{3} /$ year of water. The recycling water is averagely about $40 \%$. Besides, the groundwater demands were observed in 2010 is about $14,491,664 \mathrm{~m}^{3} /$ year.

Table 1. Groundwater demands of different activities in $2010\left(\mathrm{~m}^{3}\right)$

\begin{tabular}{|c|c|c|c|c|c|}
\hline Commune & Livings & $\begin{array}{c}\text { Breeding } \\
\text { animals }\end{array}$ & Agriculture & Industry & Total \\
\hline An Hai & 332,340 & 55,420 & $4,170,954$ & 0 & $4,558,715$ \\
\hline Phuoc Hai & 304,372 & 81,672 & $5,984,817$ & 0 & $6,370,860$ \\
\hline Phuoc Dinh & 200,371 & 85,256 & $3,276,463$ & 0 & $3,562,089$ \\
\hline Total & 837,083 & 222,347 & $13,432,234$ & 0 & $14,491,664$ \\
\hline
\end{tabular}

\section{Conceptual model}

Figure 1 describes the conceptual model of the study area. The meteorological data show that rainfall is annually $760 \mathrm{~mm}$. It is the smallest rainfall in Vietnam while evaporation is very high; about $1,723 \mathrm{~mm}$. The evaporation is much higher than the rainfall in the area. Therefore, drought is very serious problem in Ninh Thuan province. In the model, recharge was used to simulate about $40 \%$ of rainfall. The evaporation influents on groundwater level where the depth is less than $2 \mathrm{~m}$. Consideration of previous data, groundwater table depth is mostly below $2 \mathrm{~m}$.

The streams and rivers are the recharge sources for the aquifer at the study area. The conductance of streams depends on stream-bed material, water level fluctuation and width of stream as well. This conductance data is based on topography map and report of water balance (Nguyen, 2012).

\section{Geological data}

Topography and geological data are from geological map and hydrogeological map with 1:50,000 scale. Three cross-sections above (figure 2) indicate that the thickness of aquifer layer is larger from the westsouth to the east-north. The section VII-VII show that the bed-rock present in the ground surface. The thickness of aquifer is very thin. It means that groundwater is very less in the centre of the area. Moreover, there is no much difference of permeability of Holocene and Pleistocene aquifers.

Therefore, the model assumes as one aquifer to simulate groundwater flow in the area.

According to the pumping test in the study area (Quang Thuan - Ninh Thuan Co., 2013), the average permeability of the study area is about $20 \mathrm{~m} /$ day for sand materials. 

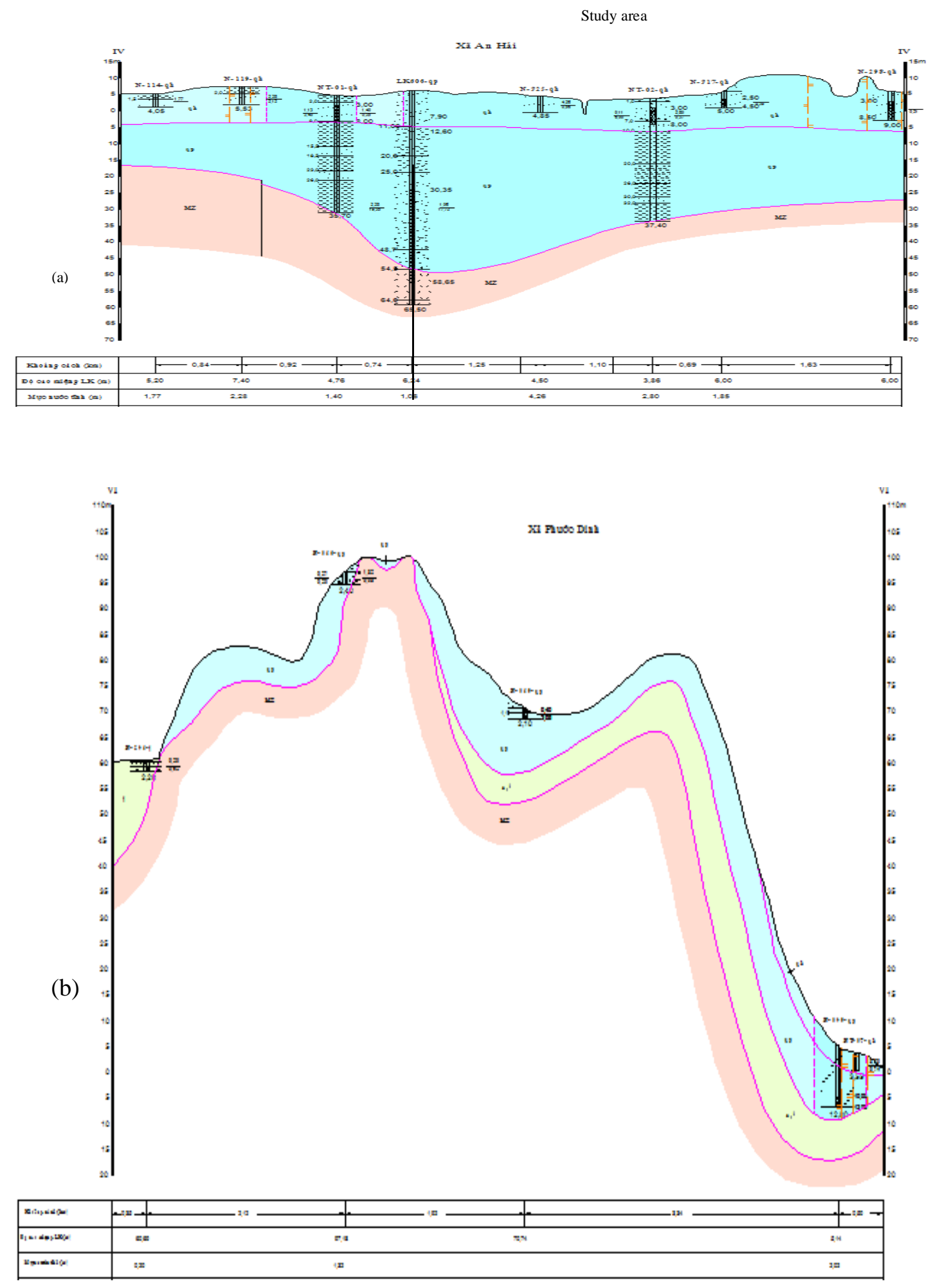


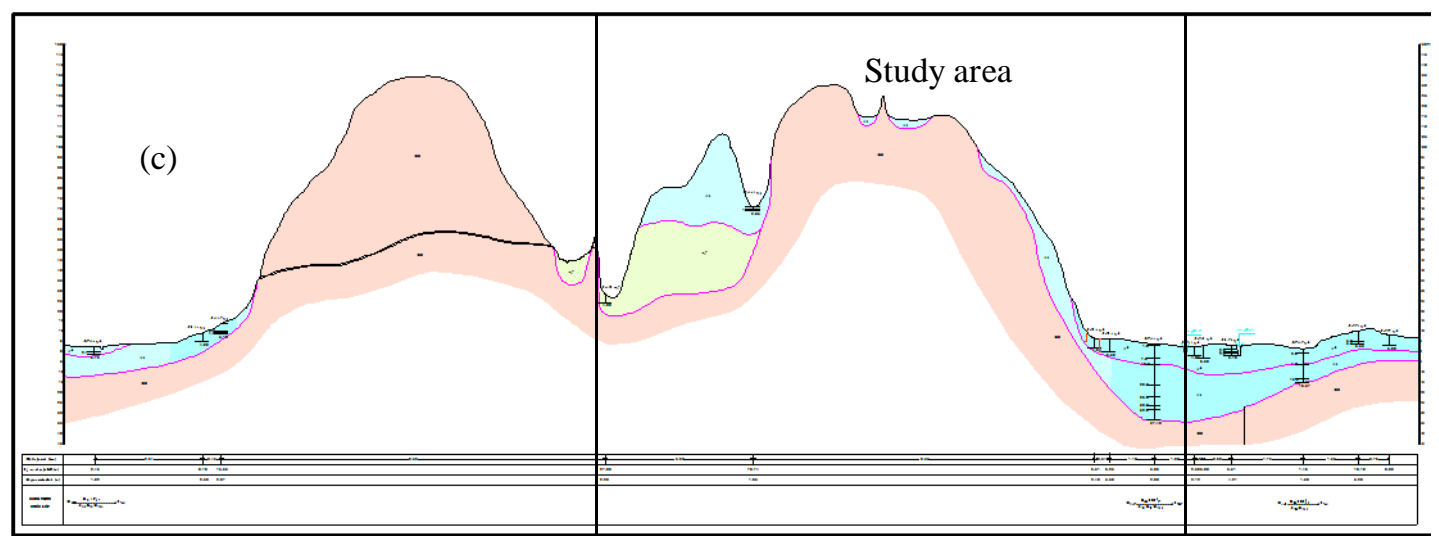

Figure 2. Hydrogeological cross-section (a- Section IV-IV, b- Section VI-VI, c- Section VII-VII, source: DONRE of Ninh Thuan)

\section{Model results and Discussion}

Groundwater flow was simulated in the steady state. Unfortunately, there is no observation data of groundwater level.

Figure 3 shows the groundwater flow pattern. Groundwater flow has two main directions. The direction of groundwater flows from the west-south to the east - north and other direction is from the westnorth to the east - south.

Table 2 shows water balance in the study area. Groundwater flows into the study area from the boundary is $167,536 \mathrm{~m}^{3} /$ day and flow out is 212,369 $\mathrm{m} 3 /$ day. The water discharge from streams to groundwater is about $130 \mathrm{~m}^{3} /$ day and water recharge from groundwater to the streams is about $118 \mathrm{~m}^{3} /$ day. The recharge from rainfall is about $84,529 \mathrm{~m}^{3} /$ day.
The water demand showing from the wells is $39,708 \mathrm{~m}^{3} /$ day. It is about $47 \%$ of rainfall recharge. It means we can use the rest of $53 \%$ of rainfall recharge for other purposes. In this case, we do not consider the increase of water demand for livings, breeding animals, agriculture in the future.

Ponce (2006) suggested that it should left at least $40 \%$ of recharge to protect groundwater crisis. As our estimation, water demand for such demands in next five years is about $84,932 \mathrm{~m}^{3} /$ day. It is over the rainfall recharge. Department of natural resources and Environment of Ninh Thuan Province plans to use groundwater for ilmenite exploitation. As mentioned above, water demand for ilmenite exploitation is about $573,068 \mathrm{~m}^{3} /$ day. It is very high than recharge, even though total flow input is still less than this water demand. It should not use groundwater as water supply for ilmenite exploitation.

Table 2. Water balance

\begin{tabular}{ccc}
\hline Sources/sinks & Flow in $\left(\mathbf{m}^{3} / \mathbf{d a y}\right)$ & Flow out $\left(\mathbf{m}^{3} / \mathbf{d a y}\right)$ \\
\hline Boundary & 167,536 & 212,369 \\
\hline Stream & 130 & 118 \\
\hline Wells & 0 & 39,708 \\
\hline Recharge & 84,529 & 0 \\
\hline Total & 252,195 & 252,195
\end{tabular}




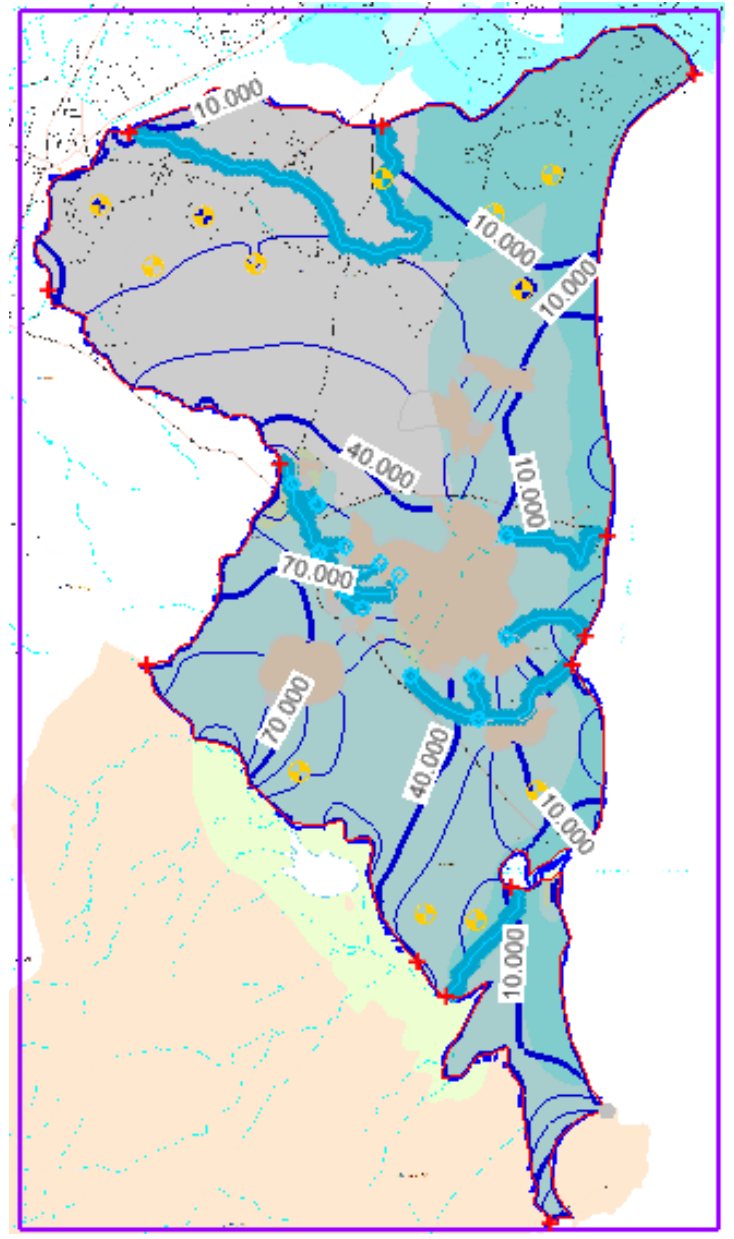

Figure 3. Groundwater flow pattern

\section{CONCLUSION}

Groundwater is limited in the study area. Recharge from rainfall is much smaller than the water demands for livings, breeding animals, agriculture in the future. For any purpose of water using, water supply for livings and other activities of local residents should be the first priority. Therefore, it is important to make planning to use groundwater and surface water reasonably for development purpose of the local area. Ilmenite reserves are good for exploitation. However, use of groundwater for the exploitation purpose should be carefully considered. The paper suggests that groundwater should not be use for this purpose in order to meet the sustainable development.

\section{Trang 38}




\section{Trữ lượng nước dưới đất và khả năng sử dụng nước dưới đất phục vụ cho việc khai thác sa khoáng Ilmenite tại tỉnh Ninh Thuận}

- Đặng Thương Huyền

Khoa Kỹ thuật Địa chất \& Dầu khí - Trường Đại học Bách khoa, ĐHQG-HCM

- Hoàng Thị Thanh Thủy

- Trịnh Hồng Phương

Trường Đại học Tài nguyên \& Môi Trường Tp.HCM

\section{TÓM TÁT:}

Việc khai thác sa khoáng ilmenite ngày càng phát triển dọc theo bờ biển miền Trung, Việt Nam. Tại tỉnh Ninh Thuận, các mỏ hầu hết sử dụng nước để tuyển quặng. Nhóm tác giả đã mô phỏng tầng nước dưới đất tại vùng nghiên cứu với một số thông số không chắc chắn nhằm trả lời cho câu hỏi liệu nước dưới đất có khả năng khai thác để phục vụ cho nhu cầu khai thác ilmenite tại Ninh Thuận không. Phần mềm GMS được sử dụng để mô phỏng sự cân bằng nước trong vùng. Nhóm tác giả

Từ khóa: Sa khoáng ilmenite, mô hình dòng chảy.

\section{TÀI LIỆU THAM KHẢO}

[1]. Nguyen, D.V., (2012). Water Resource Balance for Coastal Area in Ninh Thuan Province. Report of the Southern Institute Of Water Resources Research

[2]. Ponce,V.M,(2006). Groundwater utilization and sustainability. http://groundwater.sdsu.edu (2013). Exploration of groundwater reserve project: Water supply for ilmenite placer exploitation closing to the nuclear Power Plant

tính toán lượng nước cần dùng dựa vào trữ lượng ilmenite tại 3 xã thuộc tỉnh Ninh Thuận. Kết quả này được so sánh với khả năng cấp nước được tính toán từ mô hình. Thật không may, kết quả mô hình chỉ ra rằng, nước dưới đất không đủ để phục vụ cho việc khai thác ilmenite. Vì vậy nhóm tác giả khuyến cáo chính quyền địa phương cần lập kế hoạch sử dụng nước bền vững để bảo vệ nguồn nước trong vùng. and Coastal area. Report of Quang Thuan - Ninh Thuan Company.

[3]. Geology and Hydrogeology Map with 1:50,000 scale and theirs cross-section. Department of natural resources and Environment of Ninh Thuan Province.

[4]. GMS Tutorials. http://www.xmswiki.com/xms/GMS:Tutorials (accessed on $4^{\text {th }}$ May2014) 